\title{
PENGARUH KEPEMIMPINAN KEPALA DESA TERHADAP TINGKAT PARTISIPASI MASYARAKAT DALAM PEMANFAATAN DANA DESA (DESA PAMIJAHAN, KECAMATAN PAMIJAHAN, KABUPATEN BOGOR, JAWA BARAT)
}

\section{The Influence of Village Leadership on Public Participation Rate In The Village Fund Utilization (Case Of Pamijahan Village, Pamijahan Sub- District, Bogor District, Jawa Barat)}

\author{
Muhammad Rahmannuddin ${ }^{1)}$ dan Sumardjo ${ }^{1)}$ \\ ${ }^{1)}$ Departemen Sains Komunikasi dan Pengembangan Masyarakat, Fakultas Ekologi Manusia, \\ Institut Pertanian Bogor, Dramaga Bogor 16680, Indonesia \\ E-mail: muhrahmanudin@gmailcom; sumardjo@apps.ipb.ac.id
}

\begin{abstract}
The low level of community participation in the allocation of village funds indicates that the implementation of the village fund allocation still has not fully involved the community in the village financial management process. This is due to the weak leadership influence of the village head as the supreme leader who has full authority and responsibility in managing the region and its community. The low level of community participation has an impact on the lack of community satisfaction and trust in the village administration. This study uses a quantitative data approach supported by qualitative data in the form of in-depth interviews. Respondents consisted of 60 people divided into two categories namelynof community leaders and non-community leaders through stratified random sampling method. The results of this study indicate that there is a significant influence between the leadership of the village head on the level of community participation in the utilization of village funds.
\end{abstract}

Keywords: leadership, participation, utilization of village funds

\begin{abstract}
ABSTRAK
Rendahnya tingkat partisipasi masyarakat dalam pemanfaatan dana desa menunjukkan bahwa implementasi dana desa masih belum sepenuhnya melibatkan masyarakat di dalam proses pengelolaan keuangan desa. Hal ini disebabkan oleh lemahnya pengaruh kepemiminan kepala desa sebagai pemimpin tertinggi yang memiliki wewenang dan tanggung jawab penuh dalam mengatur wilayah dan komunitasnya. Rendahnya partisipasi masyarakat berdampak pada kurangnya kepuasan dan kepercayaan masyarakat terhadap pemerintahan desa. Penelitian ini menggunakan pendekatan data kuantitatif yang didukung data kualitatif berupa wawancara mendalam. Responden terdiri atas 60 orang yang berdasarkan tingkat ketokohan yaitu tokoh masyarakat dan non tokoh masyarakat melalui metode stratified random sampling. Hasil penelitian menunjukkan bahwa terdapat pengaruh yang signifikan antara kepemimpinan kepala desa terhadap tingkat partisipasi masyarakat dalam pemanfaatan dana desa.
\end{abstract}

Kata kunci: kepemimpinan, partisipasi, pemanfaatan dana desa

\section{PENDAHULUAN}

Rendahnya tingkat partisipasi masyarakat dalam pemanfaatan dana desa menunjukkan bahwa implementasi dana desa masih belum sepenuhnya melibatkan masyarakat di dalam proses pengelolaan keuangan desa. Hal ini disebabkan oleh lemahnya pengaruh kepemimpinan kepala desa sebagai pemimpin tertinggi yang memiliki wewenang dan tanggung jawab penuh dalam mengatur wilayah dan komunitasnya. Kebijakan yang melahirkan UU No. 6 tahun 2014 tentang desa, merupakan sebuah potensi juga tantangan besar bagi pemerintah desa dalam membangun daerahnya. Pasalnya dalam UU tersebut desa 
akan mendapatkan dana satu Miliar atau bahkan lebih untuk kemandirian desa. Melalui kebijakan Alokasi Dana Desa (ADD), Kemendes PDTT di tahun 2017 menganggarkan ADD nasional sebesar 60 triliun yang tersebar di 72 ribu desa. Kebijakan Alokasi Dana Desa merupakan instrumen penting untuk terselenggaranya otonomi dan desentralisasi di tingkat desa diharapkan memberikan peluang lahirnya pemerintahan desa yang lebih mandiri, demokratis, dekat dengan struktur dan kultur masyarakat di tingkat lokal dan bisa lebih kreatif di dalam melayani kepentingan masyarakat, terlebih 70 persen Alokasi Dana Desa (ADD) digunakan untuk pemberdayaan masyarakat dan publik. Hal demikian seharusnya membuat seluruh lapisan masyarakat desa lebih memiliki kesempatan dalam memberikan aspirasi maupun kontribusinya kepada daerah, salah satunya dalam pengelolaan keuangan desa untuk pembangunan desa yang sesuai dengan kebutuhan masyarakat.

Partisipasi pada dasarnya merupakan perwujudan asas kekeluargaan yang telah dimiliki oleh masyarakat Indonesia sejak dahulu. Faktor yang mempengaruhi partisipasi masyarakat dalam suatu program juga dapat berasal dari faktor individu masyarakat yang merupakan prasyarat umum terjadinya partisipasi yang meliputi tingkat kemauan, tingkat kemampuan dan kesempatan, Sumardjo dan Saharudin (2003).

Keberadaan seorang pemimpin dalam organisasi atau kelompok sangat dibutuhkan untuk membawa kepada tujuan yang telah ditetapkan, baik sebagai pemimpin formal maupun nonformal. Salah satu pemimpin formal yang mempengaruhi adalah kepala desa. Kepala desa merupakan pemimpin masyarakat dalam suatu desa tertentu yang diakui dan diatur oleh UU mengenai wewenang, hak dan kewajiban. Hal ini sesuai dengan UU No. 6 Tahun 2014 pasal 6 ayat 1 yaitu menyelenggarakan pemerintahan desa, melaksanakan pembangunan desa, pembinaan kemasyarakatan desa dan pemberdayaan masyarakat desa. Hasil penelitian sebelumnya Surur (2010) kepala desa dalam meningkatkan partisipasi masyarakat, program pembangunan yang sedang dilaksanakan dan bentuk partisipasi masyarakat dalam pelaksanaan program yang ada di desa ditemukan: (1) karakter masyarakat Desa Rejoagung adalah masyarakat yang mudah untuk diajak berpartisipasi, tetapi hanya pada partisipasi non financial, (2) program yang sedang dijalankan oleh Pemerintah Desa Rejoagung adalah pelaksanaan program fisik dan non fisik, (3) peran kepala desa dalam hal meningkatkan partisipasi masyarakat Desa Rejoagung adalah dengan menggunakan strategi partisipasi non finansial, melibatkan masyarakat pada MUSRENBANG dan melakukan pendekatan kepada warga masyarakat, serta (4) partisipasi masyarakat Desa Rejoagung hanya pada tahap perencanaan dan pelaksanaan, sedangkan pada tahap evaluasi masih belum terlihat.

Terdapat dua pertanyaan dalam penelitian ini (1) bagaimana tingkat partisipasi masyarakat dalam pemanfaatan dana desa di Desa Pamijahan?; dan (2) bagaimana pengaruh kepemimpinan kepala desa terhadap tingkat partisipasi masyarakat dalam pemanfaatan dana desa di Desa Pamijahan?

\section{PENDEKATAN TEORITIS}

\section{Partisipasi}

Banyak definisi partisipasi yang dikemukakan para ahli. Oakley and Dillon (1991) dalam Riska (2013), Participation is considered a voluntary contribution by the people in one or another of the public programmers supposed to contribute to national development, but the people are not expected to take part in shaping the programme or criticizing its contents". Menurut undangundang No. 25 tahun 2004 tentang Sistem Perencanaan Pembangunan Nasional, Pasal 2 ayat 4 huruf $\mathrm{D}$ bahwa partisipasi merupakan keikutsertaan masyarakat untuk mengakomodasi kepentingan mereka dalam proses penyusunan rencana pembangunan.

Bentuk partisipasi yang diberikan masyarakat dalam tahap pembangunan ada beberapa bentuk. Menurut Cohen dan Uphoff (1977) dalam Prayitno et al. (2009) membagi partisipasi ke beberapa tahapan, yaitu sebagai berikut: (1) tahap pengambilan keputusan diwujudkan dengan keikutsertaan masyarakat dalam rapat-rapat. 
Tahap pengambilan keputusan yang dimaksud disini yaitu pada perencanaan dan pelaksanaan suatu program; (2) tahap pelaksanaan yang merupakan tahap terpenting dalam pembangunan, sebab inti dari pembangunan adalah pelaksanaannya. Wujud nyata partisipasi pada tahap ini digolongkan menjadi tiga, yaitu partisipasi dalam bentuk sumbangan pemikiran, bentuk sumbangan materi, dan bentuk tindakan sebagai anggota proyek; (3) tahap menikmati hasil yang dapat dijadikan indikator keberhasilan partisipasi masyarakat pada tahap perencanaan dan pelaksanaan proyek. Selain itu, dengan melihat posisi masyarakat sebagai subjek pembangunan maka semakin besar manfaat proyek yang dirasakan, berarti proyek tersebut berhasil mengenai sasaran; dan (4) tahap evaluasi dianggap penting sebab partisipasi masyarakat pada tahap ini merupakan umpan balik yang dapat memberi masukan demi perbaikan pelaksanaan proyek selanjutnya.

\section{Faktor-Faktor yang Mempengaruhi Tingkat Partisipasi Masyarakat}

Ada beberapa faktor yang dapat mempengaruhi partisipasi masyarakat dalam suatu program, sifat faktor-faktor tersebut dapat mendukung suatu keberhasilan program namun ada juga yang sifatnya dapat menghambat keberhasilan program. Riska (2013) menyatakan faktor yang dapat mempengaruhi partisipasi masyarakat adalah usia, jenis kelamin, pendidikan, pekerjaan dan penghasilan.

Menurut Sumardjo dan Saharudin (2003) prasyarat umum terjadinya partisipasi dalam suatu kegiatan meliputi:

(1) Kemauan yaitu dorongan kehendak yang terarah pada tujuan tertentu;

(2) Kemampuan yaitu daya yang dimiliki seseorang sehingga mampu untuk berpatisipasi dalam suatu kegiataan; dan

(3) Kesempatan yaitu peluang yang dimiliki oleh seseorang untuk dapat berpartisipasi dalam kegiatan.

\section{Kepemimpinan}

Menurut Andrew (2002) kepemimpinan adalah kekuatan dinamis penting yang memotivasi dan mengoordinasikan organisasi dalam rangka mencapai tujuan. Siagian (1999) merumuskan kepemimpinan sebagai suatu kegiatan untuk mempengaruhi perilaku orang-orang agar bekerja bersama-sama menuju suatu tujuan tertentu yang mereka inginkan bersama. Berdasarkan pendapat yang dirumuskan para ahli di atas dapat diketahui bahwa konsepsi kepemimpinan secara umum menyampaikan unsur sama yang intinya adalah bahwa kepemimpinan sebagai suatu proses mempengaruhi orang lain untuk mencapai tujuan.

\section{Peran Kepemimpinan Kepala Desa}

Berdasarkan Peraturan Pemerintah No. 6 tahun 2014 Tentang Desa, Pasal 1 ayat 3 mengatakan, pemerintah desa adalah kepala desa atau yang disebut dengan nama lain dibantu perangkat desa sebagai unsur penyelenggara pemerintahan desa. Wewenang kepala desa antara lain, (a) memimpin penyelenggaraan pemerintahan desa berdasarkan kebijakan yang di tetapkan bersama Badan Permusyawaratan Desa (BPD), (b) mengajukan rancangan peraturan desa, (c) menetapkan peraturan desa yang telah mendapat persetujuan bersama BPD, dan (d) menyusun dan mengajukan rancangan peraturan desa mengenai Anggaran Pendapatan dan Belanja Desa (APBD) untuk dibahas dan ditetapkan bersama Badan Permusyawaratan Desa (BPD).

Konteks perilaku kepemimpinan, menurut Kouzes dan Posner (2012) di dalam bukunya The Leadership Challenge mengidentifikasi lima perilaku kepemimpinan untuk menyatakan bahwa menjadi pemimpin yang baik dan ideal, seseorang membutuhkan lima prinsip dalam sikap yaitu: (1) Modelling the way, yaitu mendorong para pemimpin untuk berperilaku dengan cara yang sama dan mendorong orang lain untuk berperilaku, dengan persepsi serta nilai-nilai mereka; (2) Inspired a shared vision (menginspirasi bersama), artinya berfokus pada pengembangan visi dan serangkaian tujuan bahwa setiap orang di organisasi peduli; (3) Challenge a process (menantang proses), yaitu mendorong orang menjadi inovatif untuk membuat perubahan; (4) Enabling others to act (memungkinkan orang lain untuk bertindak), yaitu mendorong orang untuk menciptakan lingkungan yang aman dan percaya bagi orang untuk berkolaborasi, percobaan; dan (5) 
Encouraging the heart (membesarkan hati), yaitu pada ketulusan hati, termasuk perayaan yang tulus yang ditujukan untuk mengakui keberhasilan masyarakat.

\section{Keuangan Desa dan Pemanfaatan Alokasi Dana Desa (ADD)}

Kebijakan Undang-Undang Nomor 6 Tahun 2014 tentang desa serta dengan ditegaskannya kebijakan Alokasi Dana Desa (ADD), merupakan instrumen penting untuk terselenggaranya otonomi dan desentralisasi di tingkat desa. Pasal 100 PP No. 43 tahun 2014 disebutkan bahwa belanja desa yang ditetapkan dalam APBDesa digunakan dengan ketentuan: Sedikitnya 70 persen dari jumlah anggaran belanja desa digunakan untuk mendanai penyelenggaraan pemerintahan desa, pelaksanaan pembangunan desa, pembinaan kemasyarakatan desa, dan pemberdayaan masyarakat desa; dan Paling banyak 30 persen dari jumlah anggaran belanja desa digunakan untuk penghasilan tetap dan tunjangan kepala desa dan perangkat desa, operasional pemerintah desa, tunjangan dan operasional Badan Permusyawaratan Desa dan insentif rukun tetangga dan rukun warga.

Prinsip Pengelolaan ADD menurut Sahdan et al. (2006), menjelaskan bahwa prinsip pengelolaan ADD harus mengikuti prinsip good governence, yaitu: (1) Partisipatif, yaitu proses pengelolaan ADD pada semua tahapan (perencanaan, pelaksanaan, pengawasan, dan evaluasi) harus melibatkan para pihak (stakeholders); (2) Transparan, yaitu semua pihak dapat mengetahui keseluruhan proses secara terbuka, serta mengupayakan agar masyarakat desa dapat menerima informasi mengenai tujuan, sasaran, hasil, dan manfaat yang diperolehnya dari setiap kegiatan yang menggunakan ADD; (3) Akuntabel, yaitu keseluruhan proses penggunaan ADD, yang meliputi peruntukkan, pelaksanaan, dan pencapaian hasil dapat dipertanggung jawabkan di depan seluruh pihak terutama masyarakat desa; dan (4) Kesetaraan, yaitu semua pihak yang terlibat dalam pengelolaan ADD mempunyai hak dan kedudukan yang sama.

\section{Kerangka Pemikiran}

Partisipasi masyarakat memiliki andil dalam keberhasilan suatu program pembangunan.
Yulianti (2012) menyatakan bahwa partisipasi masyarakat menjadi hal yang sangat penting dalam mencapai keberhasilan dan keberlanjutan program pembangunan. Partisipasi berarti keikutsertaan seseorang ataupun sekelompok masyarakat dalam suatu kegiatan secara sadar. Merujuk pada Cohen dan Uphoff (1977) dalam Prayitno et al. (2009) yaitu membagi partisipasi kedalam beberapa tahapan: (1) tahap pengambilan keputusan, (2) tahap pelaksanaan, (3) tahap menikmati hasil, dan (4) tahap evaluasi.

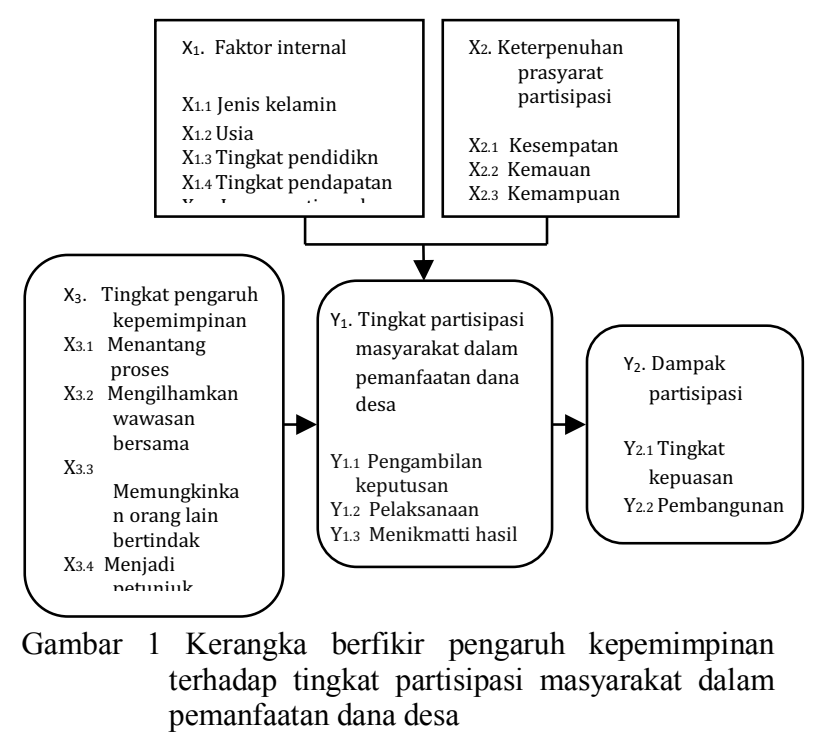

Keterangan $\rightarrow$ mempengaruhi

Pengaruh pemimpin dalam penelitian ini merujuk pada konteks perilaku kepemimpinan menurut Kouzes dan Posner (2012) yang mengidentifikasi lima perilaku kepemimpinan yaitu menantang proses, mengilhamkan wawasan bersama, memungkinkan orang lain bertindak, menjadi petunjuk jalan, dan membesarkan hati. Faktor yang mempengaruhi partisipasi masyarakat dalam suatu program dapat juga berasal dari faktor individu masyarakat sebagai prasyarat umum terjadinya partisipasi. Menurut Sumardjo dan Saharudin (2003), prasyarat umum terjadinya partisipasi dalam suatu kegiatan meliputi tingkat kemauan, tingkat kemampuan dan tingkat kesempatan. Selain itu, menurut Riska (2013) menyatakan bahwa partisipasi masyarakat dapat dipengaruhi oleh faktor internal yaitu karakteristik individu, jenis kelamin, usia, tingkat pendidikan, tingkat pendapatan, dan lamanya tinggal. 


\section{Hipotesis}

Hipotesis dalam penelitian ini disusun untuk menguji pengaruh antara kepemimpinan dengan tingkat partisipasi masyarakat. Hipotesis uji dalam penelitian ini yaitu: (1) terdapat pengaruh nyata antara kepemimpinan kepala desa dengan tingkat partisipasi masyarakat dalam pemanfaatan dana desa; (2) terdapat pengaruh nyata antara tingkat partisipasi dengan dampak partisipasi dalam pemanfaatan dana desa; (3) terdapat pengaruh nyata antara faktor internal partisipasi terhadap tingkat partisipasi masyarakat dalam pemanfaatan dana desa; dan (4) terdapat pengaruh nyata antara keterpenuhan prasyarat partisipasi terhadap tingkat partisipasi masyarakat dalam pemanfaatan dana desa.

\section{PENDEKATAN LAPANG}

Penelitian ini dilakukan secara purposive di Desa Pamijahan, Kecamatan Pamijahan, Kabupaten Bogor, Provinsi Jawa Barat dengan alasan Desa Pamijahan merupakan salah satu dari 15 desa di Kecamatan Pamijahan yang menerima anggaran dana desa dan memiliki potensi pengembangan desa yang tinggi. Selain itu dalam pemanfaatan dana desa partisipasi masyarakat dalam prosesnya belum dilibatkan secara keseluruhan. Hal ini menjadi keterwakilan sebagai masalah pokok yang dihadapi disebagian besar desa untuk diuji dan diteliti. Kegiatan penelitian ini dilaksanakan dalam jangka waktu tujuh bulan, terhitung mulai bulan April sampai dengan Oktober tahun 2017.

Populasi dari penelitian ini adalah masyarakat Desa Pamijahan dengan sampel kepala keluarga di RW 01, 03, dan 09 di Desa Pamijahan serta unit analisisnya adalah individu yang berdomisili di tiga wilayah tersebut. Penentuan responden menggunakan metode stratified random sampling brdasarkan tingkat ketokohan masyarakat dengan jumlah 60 orang.

Penelitian ini menggunakan pendekatan kuantitatif dengan metode survei dan menggunakan kuesioner sebagai instrumen analisis yang diberikan kepada responden. Data kuantitatif yang diperoleh dari kuesioner digunakan untuk mengetahui pengaruh kepemimpinan terhadap tingkat partisipasi masyarakat dalam pemanfaatan dana desa dan dianalisis dengan mengggunakan uji regresi untuk melihat pengaruh antar variabel. Model regresi yang dipakai pada penelitian ini adalah regresi linear dengan persamaan:

$\mathrm{Y}=\mathrm{A}+\mathrm{bX}$

Keterangan

$\mathrm{Y}=$ tingkat partisipasi

$\mathrm{A}=$ konstanta

$\mathrm{b}=$ nilai koefisien regresi

$\mathrm{X}_{1}=$ pengaruh kepemimpinan

Setiap peubah indikator diukur dengan skala yang berbeda-beda sesuai dengan definisi operasional. Indikator tersebut diukur dengan skala likert. Pengujian data yang dilakukan menggunakan analisis data statis dan inferensial menggunakan aplikasi Microsoft excell 2016. Selanjutnya untuk memperkuat data, dilakukan juga data kualitatif dengan analisis melalui tiga tahap yaitu reduksi data, penyajian data, dan verifikasi.

\section{HASIL DAN PEMBAHASAN}

\section{Gambaran Umum Lokasi Penelitian}

Desa Pamijahan merupakan salah satu desa di wilayah Kecamatan Pamijahan Kabupaten Bogor, Jawa Barat yang berada pada ketinggian \pm 450meter dari permukaan air laut dengan suhu berkisar antara $22-31^{\circ} \mathrm{C}$ dengan luas wilayah 396.96 Ha. Desa Pamijahan memiliki jarak 4 km dari kantor Kecamatan Pamijahan atau sekitar 10 menit jika ditempuh dengan kendaraan bermotor. Sedangkan jarak dari Desa Pamijahan ke Ibukota Kabupaten Bogor berjarak $57 \mathrm{~km}$ atau sekitar 1.5 jam jika ditempuh dengan kendaraan bermotor. Berdasarkan kondisi lahan, Desa Pamijahan terbagi dalam dua ekosistem, yaitu ekosistem lahan sawah atau kolam, serta ekosistem lahan kering atau darat. Luas lahan sawah berjumlah $191.108 \mathrm{Ha}$ dan luas lahan kering 67.5 Ha. Pemanfaatan sumber daya alam digunakan untuk pertanian dan peternakan dengan komoditas unggulan padi dan palawija.

Desa Pamijahan terdiri atas dua dusun, sembilan RW dan 31 RT dengan jumlah kepala keluarga sebanyak 3017 KK. Berdasarkan data terbaru tahun 2017 tercatat penduduk Desa Pamijahan sebanyak 11835 jiwa yang terdiri atas laki-laki 
sebanyak 5932 jiwa dan perempuan sebanyak 5 601 jiwa. Sementara itu rata-rata pertumbuhan penduduk di Desa Pamijahan mencapai 2.8 persen. Penduduk Desa Pamijahan merupakan penduduk yang tergolong heterogen. Salah satu keheterogenan penduduk dapat dilihat dari jenis mata pencaharian masyarakat Desa Pamijahan. Banyaknya masyarakat yang berprofesi sebagai petani didukung dengan luas lahan yang masih produktif terutama untuk menanam komoditas padi dan juga palawija dengan total lahan mencapai $191.11 \mathrm{Ha}$ atau sebesar 68.7 persen dari total luas wilayah Desa Pamijahan. Selain itu sebagai sarana pendukung ekonomi masyarakat, Desa Pamijahan memiliki pasar yang berlokasi di belakang kantor Desa Pamijahan dan selalu beroperasi setiap satu minggu sekali khususnya pada hari Selasa yang salah satunya menjual hasil pertanian dan peternakan dari masyarakat.

Pada tingkat pendidikan, masyarakat Desa Pamijahan memiliki tingkat pendidikan yang masih rendah. Sebesar 42.8 persen masyarakat Desa Pamijahan sebagian besar masih berada pada tingkat SD atau sederajat, tamat SMP dan SMA masing-masing sebesar 26.9 dan 21.4 persen. Walaupun demikian, Desa Pamijahan telah mengalami perkembangan dalam dunia pendidikan, hal ini dilakukan untuk meningkatkan kualitas sumber daya manusia Desa Pamijahan.

\section{Pengelolaan Dana Desa}

Pengelolaan dana desa di Desa Pamijahan bersumber dari Alokasi Dana Desa (ADD), Dana Desa (DD), Dana Provinsi, dan Anggaran Pendapatan dan Belanja Daerah (APBD). Tahun 2016 Desa Pamijahan mendapatkan bantuan dana desa sebesar 752 juta rupiah dan pada tahun 2017 sebesar 925 juta rupiah. Akan tetapi informasi dari Anggaran dan Pendapatan Belanja (APBDes) di Desa Pamijahan tahun 2017 sebesar Rp2 444.7 juta dengan rincian sumber anggaran dapat dilihat pada Tabel 1.

Berdasarkan spesifikasi dalam pemanfaatan keuangan yang bersumber dari alokasi dana desa (ADD), pengelolaan ADD Pemerintah Desa Pamijahan mengikuti ketentuan Peraturan Pemerintah No. 60 tahun 2014 tentang dana desa yang bersumber dari APBN dan Peraturan
Pemerintah No. 43 tahun 2014 tentang Peraturan Pelaksanaan Undang-Undang Nomor 6 tahun 2014 tentang desa telah diatur beberapa pokok penggunaan keuangan desa.

Tabel 1. Sumber anggaran dan pendapatan desa di Desa Pamijahan tahun 2016 dan 2017

\begin{tabular}{lcccc}
\hline \multirow{2}{*}{ Sumber Anggaran Keuangan Desa } & \multicolumn{4}{c}{ Jumlah } \\
\cline { 2 - 5 } & \multicolumn{4}{c}{ Nominal (juta rupiah) } \\
\cline { 2 - 5 } & 2016 & $(\%)$ & 2017 & $(\%)$ \\
\hline Pendapatan Asli Desa & 10.0 & 0.6 & - & - \\
Bantuan dari Provinsi (Kinerja) & - & - & 210.0 & 8.6 \\
Bantuan dari Kabupaten (Kinerja) & - & - & 650.0 & 26.6 \\
Alokasi Dana Desa & 752.0 & 41.9 & 925.0 & 37.8 \\
Penghasilan Tetap (SILTAP) & 285.0 & 15.9 & - & - \\
Bagi Hasil Pajak dan Retribusi & 175.0 & 9.8 & 84.7 & 3.6 \\
Daerah (BHPR) & & & & \\
Dana Desa (DD) & 571.0 & 31.8 & 575.0 & 23.5 \\
\hline Total & 1793.0 & 100.0 & 2444.7 & 100.0 \\
\hline
\end{tabular}

Sumber: Diolah dari data Desa Pamijahan dan Kecamatan Pamijahan tahun 2017

Tabel 2. Pemanfaatan anggaran alokasi dana desa di Desa Pamijahan tahun 2017

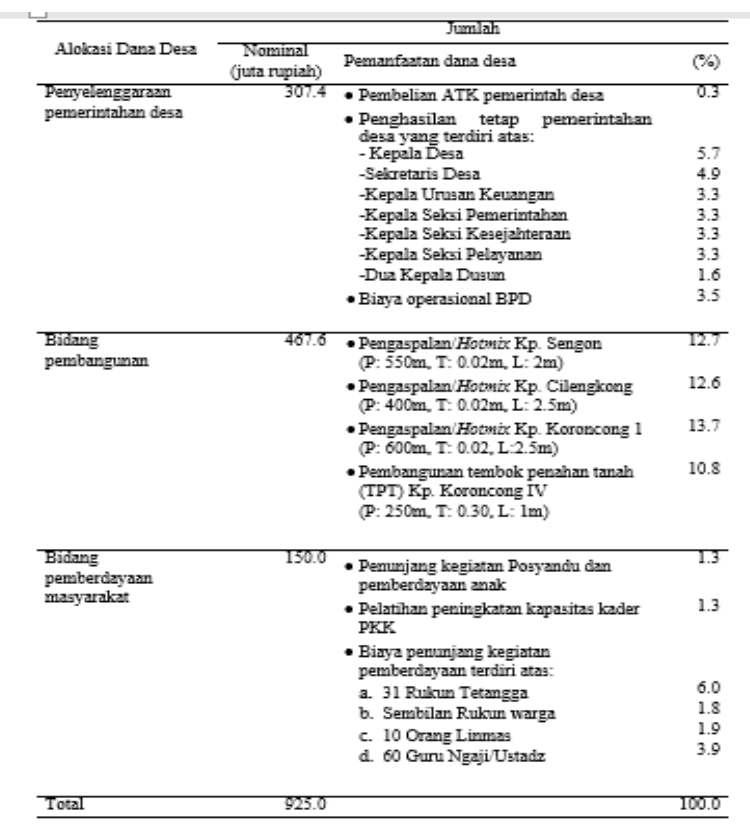

Sumber: Diolah dari Data Kecamatan tahun 2017 
Pasal 100 PP No. 43 tahun 2014 disebutkan bahwa belanja desa yang ditetapkan dalam APBDesa digunakan dengan ketentuan 70 persen digunakan untuk pembangunan dan pemberdayaan masyarakat khususnya dalam pengaspalan jalan dan tunjangan pembantu masyarakat seperti Ustadz, Linmas dan sebagainya, serta 30 persen digunakan untuk operasional pemerintahan desa dan juga Badan Pemusyawaratan Desa (BPD). Data pemanfaatan keuangan Alokasi Dana Desa di Desa Pamijahan tahun 2017 dapat dilihat di Tabel 2.

\section{Tingkat Partisipasi Masyarakat dalam Pemanfaatan Dana Desa}

Secara umum partisipasi masyarakat di Desa Pamijahan dalam pemanfaatan dana desa masih rendah yaitu 85 persen berada pada tahap pengambilan keputusan dan 81.7 persen pada tahap evaluasi terutama partisipasi non tokoh. Selain itu, untuk tingkat partisipasi masyarakat pada tahap pelaksanaan dan menikmati hasil memang sudah cukup baik berada pada kategori sedang dengan persentase masing-masing sebesar 50 persen dan 61.7 persen, walaupun memang masih terdapat 33.3 persen yang rendah partisipasinya terutama untuk non tokoh. Hal ini menunjukkan bahwa partisipasi masyarakat di Desa Pamijahan dalam pemanfaatan dana desa masih belum sepenuhnya dilibatkan atau terlibat dalam rangkaian proses partisipasi, sehingga membutuhkan upaya perbaikan agar partisipasi masyarakat dalam program pemberdayaan selayaknya mencakup keseluruhan proses mulai dari perencanaan, pelaksanaan, menikmati hasil hingga evaluasi.

\section{Tahap Pengambilan Keputusan}

Berdasarkan hasil analisis Tabel 14 terlihat bahwa secara umum tingkat partisipasi masyarakat pada tahap pengambilan keputusan tergolong rendah sebesar 85 persen, bahkan penilaian dari non tokoh sebesar 100 persen menyatakan tidak pernah dilibatkan oleh pihak pemerintah. Artinya Kepala Desa Pamijahan dalam pengambilan keputusan mengenai pemanfaatan dana desa masih bersifat dominan. Hal ini membutuhkan upaya perbaikan yang serius dikarenakan pada tahap pengambilan keputusan dan perencanaan merupakan proses awal dalam tingkatan partisipasi sehingga dalam pemanfaatan dana desa ketersediaan kesempatan kepada masyarakat untuk menyampaikan pandangannya terhadap wilayah yang seyogyanya sebagai penerima program menjadi rendah.

Tabel 3. Sebaran responden berdasarkan tingkat partisipasi pada tahap pengambilan keputusan dan tingkat ketokohan di Desa Pamijahan tahun 2017

\begin{tabular}{|c|c|c|c|c|c|c|}
\hline \multirow{3}{*}{$\begin{array}{l}\text { Partisipasi tahap } \\
\text { pengambilan } \\
\text { keputusan }\end{array}$} & \multicolumn{4}{|c|}{ Tingkat Ketokohan } & \multirow{2}{*}{\multicolumn{2}{|c|}{ Total }} \\
\hline & \multicolumn{2}{|c|}{ Tokoh } & \multicolumn{2}{|c|}{ Non-tokoh } & & \\
\hline & $\mathrm{n}$ & $\%$ & $\mathrm{n}$ & $\%$ & $\mathrm{~N}$ & $\%$ \\
\hline Rendah & 21 & 70.0 & 30 & 100 & 51 & 85.0 \\
\hline Sedang & 9 & 30.0 & 0 & 0 & 9 & 15.0 \\
\hline Tinggi & 0 & 0 & 0 & 0 & 0 & 0 \\
\hline Total & 30 & 100.0 & 30 & 100.0 & 60 & 100.0 \\
\hline
\end{tabular}

\section{Tahap Pelaksanaan}

Berdasarkan hasil analisis Tabel 15 terlihat bahwa walaupun secara umum tingkat partisipasi masyarakat pada tahap pelaksanaan sudah cukup baik dan tergolong sedang dengan persentase sebesar 50 persen, akan tetapi masih membutuhkan upaya perbaikan karena masih terdapat 28.3 persen keterlibatan masyarakat pada tahap ini masih rendah terutama untuk non tokoh.

Tabel 4 Sebaran responden berdasarkan tingkat partisipasi pada tahap pelaksanaan dan tingkat ketokohan di Desa Pamijahan tahun 2017

\begin{tabular}{cccccccc}
\hline \multirow{2}{*}{$\begin{array}{c}\text { Partisipasi tahap } \\
\text { pelaksanaan }\end{array}$} & \multicolumn{3}{c}{ Tingkat Ketokohan } & \multicolumn{3}{c}{ Total } \\
\cline { 2 - 6 } & \multicolumn{2}{c}{ Tokoh } & \multicolumn{2}{c}{ Non-tokoh } & & \\
\cline { 2 - 6 } & $\mathbf{n}$ & $\%$ & $\mathbf{n}$ & $\%$ & & N & $\%$ \\
\hline Rendah & 7 & 23.3 & 10 & 33.3 & 17 & 28.3 \\
Sedang & 11 & 36.7 & 19 & 63.4 & 30 & 50.0 \\
Tinggi & 12 & 40.0 & 1 & 3.3 & 13 & 21.7 \\
\hline Total & 30 & 100.0 & 30 & 100.0 & 60 & 100.0
\end{tabular}


Walau demikian, secara umum keterlibatan masyarakat Desa Pamijahan pada tahap pelaksanaan seperti menyebarkan informasi, memberikan sumbangan materi ataupun tenaga serta kehadiran dalam implementasi dana desa sudah cukup baik, bahkan keterlibatan tokoh masyarakat pada tahap ini tergolong tinggi dengan persentase sebesar 40 persen. Hal ini menunjukkan tokoh masyarakat dalam pelaksanaan program memiliki peran penting dan memiliki tanggung jawab sebagai pemimpin di wilayahnya serta secara umum Desa Pamijahan masih memiliki budaya gotong royong yang masih cukup kental.

\section{Tahap Menikmati Hasil}

Berdasarkan hasil analisis Tabel 16 terlihat bahwa secara umum tingkat partisipasi masyarakat pada tahap menikmati hasil tergolong sedang dengan persentase sebesar 61.7 persen. Artinya dalam implementasi dana desa sebagian besar masyarakat sudah merasakan manfaat yang diberikan yaitu dengan adanya program pembangunan infrastruktur. Walaupun demikian, masih terdapat 30 persen masyarakat pada tahap menikmati hasil masih tergolong rendah, sehingga membutuhkan upaya perbaikan. Hal ini dikarenakan program yang dilaksanakan masih diprioritaskan berdasarkan manfaat terbesar masyarakat secara umum sehingga masih ada beberapa titik yang belum terjangkau akibat keterbatasan dana.

Tabel 5 Sebaran responden berdasarkan tingkat partisipasi pada tahap menikmati hasil dan tingkat ketokohan di Desa Pamijahan tahun 2017

\begin{tabular}{cccccccc}
\hline & \multicolumn{3}{c}{ Tingkat Ketokohan } & \multicolumn{2}{c}{ Total } \\
\cline { 2 - 5 } $\begin{array}{c}\text { Partisipasi tahap } \\
\text { menikmati hasil }\end{array}$ & \multicolumn{2}{c}{ Tokoh } & \multicolumn{2}{c}{ Non-tokoh } & & \\
\cline { 2 - 6 } & n & $\%$ & n & $\%$ & N & $\%$ \\
Rendah & 6 & 20.0 & 12 & 40.0 & 18 & 30.0 \\
Sedang & 21 & 70.0 & 16 & 53.3 & 37 & 61.7 \\
Tinggi & 3 & 10.0 & 2 & 6.7 & 5 & 8.3 \\
\hline Total & 30 & 100.0 & 30 & 100.0 & 60 & 100.0 \\
\hline
\end{tabular}

\section{Tahap Evaluasi}

Berdasarkan hasil analisis Tabel 17 terlihat bahwa secara umum tingkat partisipasi masyarakat pada tahap evaluasi masih rendah dengan persentase sebesar 81.7 persen terutama non tokoh. Hal ini membutuhkan upaya perbaikan yang serius karena pada tahap evaluasi merupakan salah satu proses penting untuk mengetahui umpan balik yang dapat memberi masukan demi perbaikan pelaksanaan program selanjutnya. Rendahnya tingkat partisipasi masyarakat pada tahap ini menunjukkan bahwa keterbukaan pemerintah desa untuk melibatkan masyarakat masih rendah karena masih didominasi oleh kepala desa dalam memonitoring hasil dari pencapaian program yang telah dilaksanakan.

Tabel 6 Sebaran responden berdasarkan tingkat partisipasi pada tahao evaluasi dan tingkat ketokohan di Desa Pamijahan tahun 2017

\begin{tabular}{cccccccc}
\hline \multirow{2}{*}{$\begin{array}{c}\text { Partisipasi tahap } \\
\text { evaluasi }\end{array}$} & \multicolumn{3}{c}{ Tingkat ketokohan } & \multicolumn{3}{c}{ Total } \\
\cline { 2 - 5 } & \multicolumn{2}{c}{ Tokoh } & \multicolumn{2}{c}{ Non-tokoh } & & \\
\cline { 2 - 6 } & $\mathbf{n}$ & $\%$ & $\mathbf{n}$ & $\%$ & $\mathbf{N}$ & $\%$ \\
\hline Rendah & 20 & 66.7 & 29 & 96.7 & 49 & 81.7 \\
Sedang & 8 & 26.7 & 0 & 0 & 8 & 13.3 \\
Tinggi & 2 & 6.6 & 1 & 3.3 & 3 & 5.0 \\
\hline Total & 30 & 100.0 & 30 & 100.0 & 60 & 100.0 \\
\hline
\end{tabular}

Faktor-Faktor yang Mempengaruhi Tingkat Partisipasi Masyarakat dalam Pemanfaatan Dana Desa

\section{Karakteristik Individu (faktor internal)}

Hasil analisis menunjukkan karakteristik individu untuk golongan usia berada pada kisaran 40-50 tahun sebesar 46.7 persen yang menunjukkan usia berada pada kategori sedang, jenis kelamin didominasi oleh laki-laki sebesar 73 persen, tingkat pendidikan masih rendah dengan kelulusan SD atau sederajat diatas 50 persen, dan tingkat penghasilan termasuk rendah berada pada kisaran $<$ Rp1 355000 sebesar 60 persen. Tujuan dari pengaruh karakteristik individu ini untuk melihat sejauhmana pengaruh internal mempunyai peran penting dalam partisipasi khususnya terhadap pemanfaatan dana desa. 
Karakteristik individu yang dapat mempengaruhi partisipasi masyarakat dalam suatu program menurut Riska (2013) adalah usia, jenis kelamin, pendidikan, pekerjaan dan penghasilan.

\section{Keterpenuhan Prasyarat Partisipasi}

Prasyarat partisipasi dalam pemanfaatan dana desa di Desa Pamijahan secara umum menunjukkan tingkat kesempatan untuk terlibat dalam pemanfaatan dana desa masih rendah sebesar 58.3 persen terutama pada non tokoh. Padahal untuk tingkat kemauan dan kemampuan lebih dari 50 persen menyatakan tertarik dan siap untuk terlibat dalam implementasi dana desa. Hal ini membutuhkan perbaikan dalam keterpenuhan prasyarat partisipasi dari pemerintah desa guna meningkatkan partisipasi masyarakat. Partisipasi merupakan keikutsertaan masyarakat untuk mengakomodasi kepentingan mereka dalam proses penyusunan rencana pembangunan.

\section{Pengaruh Kepemimpinan Kepala Desa terhadap Tingkat Partisipasi Masyarakat dalam Pemanfaatan Dana Desa}

\section{Kepemimpinan Kepala Desa dalam Pemanfatan Dana Desa}

Pengaruh kepemimpinan Kepala Desa Pamijahan secara umum berada pada tingkat partisipasi rendah dengan persentase di atas 50 persen terutama untuk non tokoh. Hal ini membutuhkan upaya perbaikan yang serius dari kepala desa sebagai pemimpin tertinggi. Masyarakat menilai pengaruh kepala desa dalam pemanfaatan dana desa, baik dalam menantang proses, menambahkan wawasan masyarakat, memungkinkan orang lain bertindak, menjadi petunjuk jalan serta membesarkan hati dalam proses pemanfaatan dana desa masih rendah. Hal ini menunjukkan dalam proses pelibatan pengelolaan dana desa masih didominasi oleh kepala desa dan hanya terbatas pada kategori tokoh masyarakat yang cenderung memiliki hubungan dekat dengan pemerintahan desa. Alasan rendahnya pengaruh kepemimpinan kepala desa terhadap tingkat partisipasi masyarakat dalam pemanfaatan dana desa adalah sistem yang dibangun kepala desa untuk menjadi pembantu/perangkat desa yang belum mewakili secara keseluruhan di tiap wilayah karena keterwakilan masih terbatas pada orang-orang yang dahulu menjadi tim sukses dalam pemilihan kepala desa sebelumnya.

\section{Mengilhamkan Wawasan Bersama}

Berdasarkan hasil analisis Tabel 29 terlihat bahwa secara umum masyarakat menyatakan peran kepemimpinan Kepala Desa Pamijahan kurang memberikan wawasan dalam pemanfaatan dana desa dengan kategori rendah sebesar 65 persen terutama kepada non tokoh, sehingga membutuhkan upaya perbaikan dari kepala desa untuk lebih memberikan wawasan kepada masyarakat terutama dalam menjelaskan visi, pencapaian tujuan, hasil, dan manfaat yang diperoleh masyarakat dari implementasi dana desa. Hal ini mengindikasikan bahwa kepala desa kurang mampu untuk memahami kebutuhan, impian, harapan dan aspirasi masyarakat yang dipimpinnya. Kurangnya sosialisasi oleh pemerintahan desa dalam menjelaskan visi dan pencapaian program mengakibatkan masyarakat secara keseluruhan kurang mendapat informasi dan pemahaman khususnya terkait pemanfaatan dana desa. Data mengenai konteks perilaku kepemimpinan mengilhamkan wawasan bersama dapat dilihat dalam Tabel 8.

\begin{tabular}{|c|c|c|c|c|c|c|c|}
\hline Tabel 8 & \multicolumn{7}{|c|}{$\begin{array}{l}\text { mengilhamkan wawasan bersama dan } \\
\text { tingkat ketokohan di Desa Pamijahan } \\
\text { tahun } 2017\end{array}$} \\
\hline \multirow{3}{*}{\multicolumn{2}{|c|}{$\begin{array}{l}\text { "Mengilhamkan } \\
\text { Wawasan } \\
\text { Bersama" }\end{array}$}} & \multicolumn{4}{|c|}{ Tingkat ketokohan } & \multirow{2}{*}{\multicolumn{2}{|c|}{ Total }} \\
\hline & & \multicolumn{2}{|c|}{ Tokoh } & \multicolumn{2}{|c|}{ Non-tokoh } & & \\
\hline & & $\mathbf{n}$ & $\%$ & $\mathbf{n}$ & $\%$ & $\mathbf{N}$ & $\%$ \\
\hline \multicolumn{2}{|c|}{ Rendah } & 15 & 50.0 & 24 & 80.0 & 39 & 65.0 \\
\hline \multicolumn{2}{|c|}{ Sedang } & 14 & 46.7 & 3 & 10.0 & 17 & 28.3 \\
\hline \multicolumn{2}{|c|}{ Tinggi } & 1 & 3.3 & 3 & 10.0 & 4 & 6.7 \\
\hline \multicolumn{2}{|c|}{ Total } & 30 & 100.0 & 30 & 100.0 & 60 & 100.0 \\
\hline
\end{tabular}

\section{Menantang Proses}

Berdasarkan hasil analisis Tabel 7 terlihat bahwa secara umum masyarakat menilai kepemimpinan Kepala Desa Pamijahan kurang berani menantang proses dengan kategori rendah sebesar 53.4 persen terutama penilaian dari non tokoh. Artinya Kepada Desa Pamijahan kurang berani mengkritisi dari kebiasaan dan aturan-aturan yang telah ditetapkan. Data mengenai konteks 
perilaku kepemimpinan menantang proses dapat dilihat dalam Tabel 7.

\begin{tabular}{|c|c|c|c|c|c|c|}
\hline Tabel 7 & $\begin{array}{l}\text { Sebaran } \\
\text { penilaian } \\
\text { menantang } \\
\text { ketokohan } \\
2017\end{array}$ & & $\begin{array}{l}\text { onden } \\
\text { ran } \\
\text { roses } \\
\text { Desa } P\end{array}$ & $\begin{array}{r}b \\
\text { kep } \\
\text { dar } \\
\text { amija }\end{array}$ & $\begin{array}{l}\text { serda } \\
\text { emin } \\
\text { ahan }\end{array}$ & $\begin{array}{l}\text { arkan } \\
\text { jinan } \\
\text { agkat } \\
\text { ahun }\end{array}$ \\
\hline \multirow{3}{*}{$\begin{array}{l}\text { "Menantang } \\
\text { Proses" }\end{array}$} & \multicolumn{4}{|c|}{ Tingkat Ketokohan } & \multirow{2}{*}{ Total } & \multirow[b]{3}{*}{$\%$} \\
\hline & \multicolumn{2}{|l|}{ Tokoh } & \multicolumn{2}{|l|}{ Non-tokoh } & & \\
\hline & $\mathrm{n}$ & $\%$ & $\mathrm{n}$ & $\%$ & $\mathrm{~N}$ & \\
\hline Rendah & 11 & 36.7 & 21 & 70.0 & 32 & 53.4 \\
\hline Sedang & 18 & 60.0 & 8 & 26.7 & 26 & 43.3 \\
\hline Tinggi & 1 & 3.3 & 1 & 3.3 & 2 & 3.3 \\
\hline Total & 30 & 100.0 & 30 & 100.0 & 60 & 100.0 \\
\hline
\end{tabular}

\section{Memungkinkan Orang Lain Bertindak}

Berdasarkan hasil analisis Tabel 30 terlihat secara umum kepemimpinan Kepala Desa Pamijahan dalam berperan memungkinkan orang lain bertindak masih rendah yaitu sebesar 61.6 persen terutama kepada non tokoh masyarakat, sehingga membutuhkan upaya perbaikan dari kepala desa untuk lebih memberikan kepercayaan kepada masyarakat terutama dalam implementasi dana desa.

Tabel 9 Sebaran responden berdasarkan penilaian peran memungkinkan orang lain bertindak dan tingkat ketokohan di Desa Pamijahan tahun 2017

\begin{tabular}{|c|c|c|c|c|c|c|}
\hline \multirow{3}{*}{$\begin{array}{c}\text { "Memungkinkan } \\
\text { Orang Lain } \\
\text { Bertindak" }\end{array}$} & \multicolumn{4}{|c|}{ Tingkat Ketokohan } & \multirow{2}{*}{\multicolumn{2}{|c|}{ Total }} \\
\hline & \multicolumn{2}{|c|}{ Tokoh } & \multicolumn{2}{|c|}{ Non-tokoh } & & \\
\hline & $\mathbf{n}$ & $\%$ & $\mathrm{n}$ & $\%$ & $\mathbf{N}$ & $\%$ \\
\hline Rendah & 16 & 53.3 & 21 & 70.0 & 37 & 61.6 \\
\hline Sedang & 14 & 46.7 & 8 & 26.7 & 22 & 36.8 \\
\hline Tinggi & 0 & 0 & 1 & 3.3 & 1 & 1.6 \\
\hline Total & 30 & 100.0 & 30 & 100.0 & 60 & 100.0 \\
\hline
\end{tabular}

Hal ini mengindikasikan Kepala Desa Pamijahan masih belum memberikan kepercayaan atau pendelegasian wewenang kepada masyarakat khususnya perwakilan masyarakat dalam hal ini RT atau RW untuk melaksanakan tugasnya yang lebih memahami kondisi masyarakat tanpa melanggar aturan-aturan yang telah ditetapkan khususnya terkait pemanfaatan dana desa.

\section{Menjadi Petunjuk Jalan}

Berdasarkan hasil analisis Tabel 10 terlihat secara umum masyarakat menilai Kepala Desa Pamijahan berperan sebagai petunjuk jalan bagi masyarakat masih rendah dengan persentase sebesar 50 persen terutama kepada non tokoh masyarakat, sehingga membutuhkan upaya perbaikan dari kepala desa untuk lebih memberikan pengarahan/wawasan kepada masyarakat terutama dalam implementasi dana desa.

Tabel 10 Sebaran responden berdasarkan penilaian peran kepemimpinan menjadi petunjuk jalan dan tingkat ketokohan di Desa Pamijahan tahun 2017

\begin{tabular}{cccccccc}
\hline & \multicolumn{3}{c}{ Tingkat Ketokohan } & & \multicolumn{2}{c}{ Total } \\
\cline { 2 - 6 } $\begin{array}{c}\text { Menjadi Petunjuk } \\
\text { Jalan" }\end{array}$ & \multicolumn{2}{c}{ Tokoh } & \multicolumn{2}{c}{ Non-tokoh } & & \\
\cline { 2 - 6 } & $\mathrm{n}$ & $\%$ & $\mathrm{n}$ & $\%$ & $\mathrm{~N}$ & $\%$ \\
\hline Rendah & 9 & 30.0 & 21 & 70.0 & 30 & 50.0 \\
Sedang & 20 & 66.7 & 7 & 23.3 & 27 & 45.0 \\
Tinggi & 1 & 3.3 & 2 & 6.7 & 3 & 5.0 \\
\hline Total & 30 & 100.0 & 30 & 100.0 & 60 & 100.0 \\
\hline
\end{tabular}

Hal ini menunjukkan kepala desa masih belum mampu memberikan wawasan untuk memecahkan masalah yang dihadapi para bawahannya dalam penyelesaian tugas maupun visi yang akan dilakukan. Data mengenai konteks perilaku kepemimpinan menjadi petunjuk jalan dapat dilihat dalam Tabel 10.

\section{Membesarkan Hati}

Berdasarkan hasil analisis Tabel 32 terlihat secara umum sebesar 53.3 persen masyarakat menyatakan bahwa Kepala Desa Pamijahan masih rendah dalam membesarkan hati masyarakat terutama kepada non tokoh masyarakat. Hal ini dikarenakan masyarakat menilai kepala desa belum bisa menghargai setiap usaha individu maupun masyarakat dalam pelaksanaan program pembangunan khususnya pemanfaatan dana desa. Kurangnya perhatian dan apresiasi kepala desa kepada masyarakat 
menyebabkan penilaian masyarakat juga rendah dalam memotivasi dan membesarkan hati.

\begin{tabular}{|c|c|c|c|c|c|c|}
\hline \multicolumn{6}{|c|}{ Tabel 11 Sebaran responden berdasarkan } & \\
\hline raber 11 s & laia & per & IIC & Desa & Pam & dan \\
\hline \multirow{3}{*}{$\begin{array}{l}\text { "Membesarkan } \\
\text { Hati" }\end{array}$} & \multicolumn{4}{|c|}{ Tingkat Ketokohan } & \multirow{2}{*}{\multicolumn{2}{|c|}{ Total }} \\
\hline & \multicolumn{2}{|c|}{ Tokoh } & \multicolumn{2}{|c|}{ Non-tokoh } & & \\
\hline & $\mathrm{n}$ & $\%$ & $\mathbf{n}$ & $\%$ & $\mathbf{N}$ & $\%$ \\
\hline Rendah & 9 & 30.0 & 23 & 76.7 & 32 & 53.3 \\
\hline Sedang & 21 & 70.0 & 5 & 16.6 & 26 & 43.3 \\
\hline Tinggi & 0 & 0 & 2 & 6.7 & 2 & 3.4 \\
\hline Total & 30 & 100.0 & 30 & 100.0 & 60 & 100.0 \\
\hline
\end{tabular}

\section{Pengaruh Kepemimpinan Kepala Desa terhadap Tingkat Partisipasi Masyarakat dalam Pemanfaatan Dana Desa}

Hasil uji pengaruh antara kepemimpinan kepala desa terhadap tingkat partisipasi masyarakat dalam pemanfaatan dana desa menunjukkan memiliki pengaruh dan bernilai positif terhadap tingkat partisipasi, dimana peningkatan pengaruh kepemimpinan akan meningkatkan tingkat partisipasi masyarakat dalam pemanfaatan dana desa. Hal ini menunjukkan adanya perubahan bersifat searah yang berarti semakin tinggi pengaruh kepemimpinan kepala desa maka semakin tinggi tingkat partisipasi masyarakat dalam implementasi dana desa.

Tabel 12 Koefisien regresi pengaruh kepemimpinan kepala desa terhadap tingkat partisipasi masyarakat dalam pemanfaatan dana desa di Desa Pamijahan tahun 2017

\begin{tabular}{lcccc}
\hline & \multicolumn{4}{c}{ Koefisien } \\
\cline { 2 - 5 } Variabel & $\begin{array}{c}\text { Koefisien Tidak } \\
\text { Terstandarisasi } \\
\end{array}$ & Std.Enor & $\begin{array}{c}\text { Koefisien } \\
\text { Terstandarisasi } \\
\text { Beta }(\beta)\end{array}$ & Signifikansi \\
\hline (Constant) & 0.110 & 3.527 & & $0.000^{\circ *}$ \\
Penganuh & 0.909 & 0.246 & 0.436 & $0.000^{\circ *}$ \\
Kepemimpinan & 13.616 & & & \\
UjiF & 0.000 & & & \\
Sig & 0.190 & & & \\
R Square & 0.176 & & & \\
Adjusted R Square & & & & \\
\hline
\end{tabular}

Keterangan: * Nyata pada $\mathrm{p}<0.05 ; * *$ Sangat nyata pada $\mathrm{p}<0.01$

Koefisien determinasi (R-Square) menunjukkan nilai sebesar 0.190 yang berarti tingkat partisipasi sebesar 19 persen dapat dipengaruhi oleh kepemimpinan kepala desa, sedangkan sisanya yaitu 81 persen dijelaskan oleh faktor-faktor lain yang tidak dianalisis dalam penelitian ini. Hasil analisis persamaan pengaruh kepemimpinan kepala desa terhadap tingkat partisipasi masyarakat dalam pemanfaatan dana desa disajikan pada Tabel 12 .

Hasil analisis menunjukkan bahwa kepemimpinan (beta $=0.909$ ) berpengaruh positif signifikan terhadap tingkat partisipasi. Hal ini berarti setiap kenaikan satu satuan pengaruh kepemimpinan akan menaikan kinerja sebesar 0.909 poin dengan nilai $R$ Square 0.190 . Uji-F menunjukkan bahwa kepemimpinan kepala desa yang mempengaruhi tingkat partisipasi masyarakat dalam pemanfaatan dana desa dan secara statistik nyata pada taraf 0.000 . Berikut persamaan regresi linear yang digunakan:

$\mathrm{Y}=0.110+0.909 \mathrm{X}_{1}$

Keterangan
$\mathrm{Y}=$ Tingkat partisipasi
$\mathrm{X}_{1}=$ Kepemimpinan kepala desa

Hal ini dikarenakan kepala desa masih menjadi kunci dalam kebijakan pemanfaatan dana desa, dan dalam praktik proses pengelolaan pemanfaatan dana desa belum sepenuhnya melibatkan tokoh masyarakat maupun non tokoh masyarakat, sehingga tingkat partisipasi masyarakat mulai dari proses perencanaan, menikmati hasil dan evaluasi berada pada kategori rendah. Akan tetapi, untuk proses pelaksanaan partisipasi berada dalam kategori sedang. Hal ini karena budaya gotong royong yang ada di Desa Pamijahan masih cukup kental.

\section{SIMPULAN DAN SARAN}

\section{Simpulan}

Berdasarkan hasil penelitian maka secara umum dapat disimpulkan bahwa rendahnya tingkat partisipasi masyarakat dalam pemanfaatan dana desa di Desa Pamijahan sangat dipengaruhi oleh kepemimpinan kepala desa. Secara khusus 
berdasarkan hasil penelitian dapat disimpulkan sebagai berikut:

1. Tingkat partisipasi masyarakat dalam pemanfaatan dana desa di Desa Pamijahan rendah. Salah satu faktor rendahnya tingkat partisipasi adalah rendahnya keterpenuhan kesempatan masyarakat untuk terlibat dalam pemanfaatan dana desa. Padahal kemauan dan kemampuan masyarakat Desa Pamijahan untuk terlibat dalam pemanfaatan dana desa berada pada kategori sedang yang artinya masyarakat memiliki keinginan untuk mengetahui dan terlibat dalam keseluruhan proses pemanfaatan dana desa. Hal ini menyebabkan partisipasi masyarakat hanya berada pada tahap pelaksanaan dan tahap menikmati hasil, sedangkan pada tahap pengambilan keputusan dan tahap evaluasi dalam prosesnya masih didominasi oleh kepala desa dan belum sepenuhnya melibatkan tokoh maupun masyarakat secara umum.

2. Secara umum pengaruh kepemimpinan Kepala Desa Pamijahan terhadap tingkat partisipasi masyarakat dalam pemanfaatan dana desa rendah. Kepemimpinan kepala desa berpengaruh positif dan signifikan terhadap tingkat partisipasi masyarakat. Artinya rendahnya pengaruh kepemimpinan maka rendah pula keterlibatan masyarakat dalam implementasi dana desa dan begitupun sebaliknya. Hal ini dikarenakan sistem keterwakilan di setiap wilayah sebagai pembantu desa masih didominasi oleh orangorang yang dekat dan membantu dalam proses pemenangan pemilihan kepala desa, sehingga aspirasi masyarakat belum sepenuhnya terwakili. Masyarakat Desa Pamijahan menilai kepemimpinan kepala desa kurang mampu untuk memahami kebutuhan, impian, harapan, dan aspirasi masyarakat karena kurangnya pelibatan masyarakat dalam rangkaian proses pemanfaatan dana desa. Rendahnya pengaruh kepemimpinan dan kesempatan untuk terlibat dalam pemanfaatan dana desa menyebabkan tingkat kepuasan masyarakat sebagai dampak dari partisipasi menjadi rendah.

\section{Saran}

Berdasarkan hasil penelitian, maka terdapat beberapa saran yang bisa dijadikan masukan sebagai bahan pertimbangan:

1. Pemerintah desa seyogyanya melibatkan para stakeholder khususnya RT atau pun RW sebagai representasi perwakilan wilayah masyarakat dan memberikan peluang yang lebih besar kepada masyarakat untuk berpartisipasi dalam pemanfaatan dana desa. Selain itu, melakukan sosialisasi secara intens dan transparan mengenai dana kepada masyarakat terhadap penggunaan dana desa baik yang telah ataupun yang akan dilakukan. Laporan realisasi dan laporan pertanggungjawaban realisasi pelaksanaan pemanfaatan dana desa diinformasikan kepada masyarakat secara tertulis dan dengan media informasi yang mudah diakses oleh masyarakat sehingga meningkatkan partisipasi masyarakat mulai dari perencanaan hingga evaluasi.

2. Kepala desa sebagai pemimpin seyogyanya mampu memahami kebutuhan masyarakat melalui pendekatan partisipatif agar proses pemanfaatan dana desa melalui programprogram pembangunan desa menjadi lebih efektif. Selain itu pelibatan masyarakat dalam semua rangkaian proses implementasi dana desa baik perencanaan, pelaksanaan, menikmati hasil dan evaluasi perlu ditingkatkan sehingga dampak partisipasi menjadi lebih baik. Selain itu kepala desa mempunyai peranan yang penting yang dapat mempengaruhi keberhasilan suatu pembangunan desa diharapkan juga memberikan inisiatif, inovasi, motivasi, dan tanggung jawab yang baik dalam menggerakkan pembangunan desa.

\section{DAFTAR PUSTAKA}

Adisasmita R. 2010. Membangun Desa Partisipatif. Yogyakata (ID): Graha Ilmu.

Akhdiyanti NS. 2015. Strategi Penguatan Partisipasi dan Kapasitas Desa dalam Pengelolaan Alokasi Dana Desa di Desa Sekongkang Atas. [Tesis]. Bogor (ID): Institut Pertanian Bogor. Dapat 
diunduh dari:http: //repository.ipb.ac.id/handl e/123456789/78997

Andrew JD. 2002. The Complete Ideal's Guides: Leadership. Ed ke-2. Wibowo Tri BS, penerjemah. Jakarta (ID): Prenada Media.

Anugra P. 2015. Pengaruh Kepemimpinan dan Motivasi terhadap Komitmen Pegawai Dinas TPHP2KKP Kabupaten Belitung. [Tesis]. Bogor (ID): Institut Pertanian Bogor. Dapat diunduh dari: http://repository.ipb ac.id/ handle/ 1234 56789/78686

Dewi DIK, Rakhmania DS. 2016. Hubungan Partisipasi dan Kepuasan Masyarakat dalam Program Revitalisasi Kawasan Braga Kota Bandung [Internet]. [Diunduh 2017 Maret 14]; Vol.- 37 (1), 2016, 17-25. Semarang (ID): Universitas Diponegoro. Dapat diunduh dari:http://journal .undip. ac.id /index. Php /teknik/article/ viewFile/9189/8795

Faisal MA, Choirul, Stefanus PR. 2013. Partisipasi Masyarakat dalam Pemerataan Pembangunan Infrastruktur Jalan (Studi Kasus di Kecamatan Lawang Kabupaten Malang) [Internet]. [Diunduh 2016 November 15]; Vol. 16, Nomor 2, Juni 2013: 94-101. Malang (ID). Universitas Brawijaya. Dapat diunduh dari: http://administrasipublik.Studentjournal.ub.ac.i d/index.php/jap/article/vie w/744

Ghozali I. 2005. Aplikasi Analisis Multivariate dengan SPSS.Semarang(ID): Badan Penerbit UNDIP.

Hardiyanti S. (tahun tidak diketahui). Pengaruh Gaya Kepemimpinan terhadap Disiplin Kerja Aparat Kelurahan Motoboi Besar [Internet]. [Diunduh 2016 November 14]. Bali (ID): Universitas Udayana Denpasar. Dapat diunduh dari: http:/ ejo

urnal.unsrat.ac.id/index.php/jurnaleksekutif/art icle/view/5183

Kharisma DV, Anwar M, Supranoto. 2013. Implementasi Kebijakan Pemanfaatan Alokasi Dana Desa [Internet]. [Diunduh 22 Desember 2016]; Vol. 12, Nomor 2, Januari 2013: 94-103. Jember (ID): FISIP Universitas Jember. Dapat diunduh dari: http://ejournal.unri.ac.id/index.php/JIANA/arti $\underline{\text { cle/vie } w / 1723}$

Kouzes J, Posner BZ. 2012. The Leadership Challenge. New York(US): Wiley.

Nurul H. 2012. Kepemimpinan Adat dalam Kepatuhan Masyarakat pada Norma Adat (Studi Kasus di
Kasepuhan Sinar Resmi Desa Sirnaresmi Kecamatan Cisolok Kabupaten Sukabumi Jawa Barat). [Tesis]. Bogor (ID): Institut Pertanian Bogor. Dapat diunduh dari: http://repository.ipb.ac.id/handle/123456789/6 14 93? show=full

Prayitno D, Pujoyono W, Warsono H. 2009. Analisis Rendahnya Partisipasi Masyarakat pada Implementasi Program Wajib Belajar Sembilan Tahun (Studi Kasus di Distrik Semangga Kabupaten Merauke). JIAKP [Internet]. [Diunduh 2017 Oktober 12]; Vol. 6, No. 1, Januari 2009:13-36. Semarang(ID): Universitas Dipenogoro. Dapat diunduh pada: http://ejournal.undip.ac.id/in dex.php/dialogue/art icle/viewFile/418/298

Raharjo T, Sjamsiar S, Imam H. 2013. Implementasi Kebijakan Alokasi Dana Desa (ADD) Tahun 2011 di Desa Jembul dan Desa Sumengko Kecamatan Jatirejo Kabupaten Mojokerto [Internet]. [Diunduh 2016 Desember 21]; Vol. 16, No. 1 (2013). Malang (ID): Universitas Brawijaya. Dapat diunduh dari: http://ww w.wacana.ub.ac.id/index.php/wacana/article/vi $\underline{\mathrm{ew} / 273}$

Riska A. 2013. Tangga Partisipasi Manipulasi [Internet]. [Diunduh 2016 Desember 26]; Vol. 1, No. 1. Malang (ID). Universitas Brawijaya. Dapat diunduh dari: https://www.academia.edu/9839021/Tangga_P artisipasi Manipulasi

Sahdan G, Iswari P, Zamroni S. 2006. ADD untuk Kesejahteraan Rakyat Desa. Yogyakarta (ID). Forum Pengembangan Pembaharuan Desa (FPPD).

Satyawati R. 2013. Pengaruh Gaya Kepemimpinan dan Budaya Organisasi terhadap Kepuasan Kerja yang Berdampak pada Kinerja Keuangan [Internet]. [Diunduh 2016 Desember 11]; Vol 6.1 (2014):17-32. Bali (ID): Universitas Udayana Denpasar. Dapat diunduh dari:http://ojs.unud.ac.id/index.php/akuntansi/a rticl e/downl oad/7776/5864

Siagian SP. 1999. Tehnik Menumbuhkan dan Memelihara Perilaku Organisasional. Jakarta (ID): Haji Mas Agung.

Singarimbun M, Effendi S. 1989. Metode Penelitian Survei. Jakarta (ID): LP3ES.

Slamet Y. 1994. Pembangunan Masyarakat Berwawasan Partisipasi. Surakarta(ID): Sebelas Maret University Press. 
Sumardjo dan Saharudin. 2003. Metode-metode Partisipatif dalam Pengembangan Masyarakat. Jurusan Ilmu-ilmu Sosial Ekonomi Faperta. Bogor(ID): Institut Pertanian Bogor.

Supriyatno AR, Sumardjo, Gani DS, Sugihen BG. 2008. Model Peningkatan Partisipasi Petani Sekitar Hutan dalam Pengelolaan Hutan Kemiri Rakyat: Kasus Pengelolaan Hutan Kemiri Kawasan Pegunungan Bulusaraung Kabupaten Maros Provinsi Sulawesi Selatan, Jurnal Penelitian Sosial dan Ekonomi Kehutanan [Internet]. [Diunduh 2017 Januari 3]; Vol. 8 No. 3 September 2011, Hal. 176 - 195. Makassar (ID): Balai Diklat Kehutanan Makassar. Dapat diunduh dari:http://ejournal.Fordamof.org/ejournallitbang/in dex.php /JPSE/ar ticle /view/ 221

Surur F. 2010. Partisipasi Pembangunan. e-Jurnal partisipasi [Internet]. [Diunduh 2016 November 20]; Volume 2 Nomor 10, Nopember $2010 \mathrm{hlm}$ 12-23. Malang (ID): Universitas Brawijaya. Dapat diunduh dari:http://www.ub.ac.id/inde $\underline{\text { x.Php/wacana/ar ticle/view/5 }}$

Surya W. 2006. Pengaruh Kepemimpinan dan Motivasi Kerja terhadap Prestasi Kerja Pegawai Pusdiklat Pegawai Departemen Sosial RI [Internet]. [Diunduh 2016 November 20]; Volume 2 Nomor 18, April 2009. Bogor (ID): Institut Pertanian Bogor. Dapat diunduh dari:http://repository.ipb.ac.id/handle/123456 $\underline{789 / 10287}$

Syamsidar. 2015. Implementasi Kebijakan Alokasi Dana Desa (ADD) di Kecamatan Marawola Kabupaten Sigi. e-Jurnal Katalogis [Internet]. [Diunduh 2016 Desember 27]; Volume 3 Nomor 11, Nopember 2015 hlm 12-23. Ambon (ID): Universitas Tadulako. Dapat diunduh dari:http://www.wacana.utad.ac.id/ind ex.Php/waca na/article/view/273

[UU] Undang-Undang No. 6 Tahun 2014 Tentang Desa

[UU] Undang-Undang No. 32 Tahun 2004 Tentang Pemerintahan Daerah

Wiradnyana O, Norken, Dharma S. 2013. Partisipasi Masyarakat Pemakai Air dalam Operasi dan Pemeliharaan Embung di Kabupaten Karangasem [Internet]. [Diunduh 2016 Desember 22]; Vol. 1, No.1 Januari 2013. Bali (ID): Universitas Udayana. Dapat diunduh dari:http://id.portalgaruda.org/index.php?ref $=$ b $\underline{\text { ro } w s e \& \bmod =\text { vie warticle } \& \text { ar ticle }=14246}$
Wiriadihardja MH. 1987. Dimensi Kepemimpinan dalam Manajemen. Jakarta(ID): Balai pustaka.

Wulandari R. 2013. Analisis Partisipasi Masyarakat dan Kepemimpinan terhadap Tingkat Keberhasilan Proyek Program Nasional Pemberdayaan Masyarakat (PNPM) Mandiri Perdesaan di Kecamatan Gerokgak, Buleleng. [Tesis]. Bali (ID): Universitas Udayana Denpasar. Dapat diunduh dari: https://scholar.Goo

gle.com/scholar?q=Pengaruh + Kepemimpinan + Camat+terhadap+Peningkatan+Partisipasi $+\mathrm{Ma}$ syarakat + dalam + Pembangunan.+ Medan $\& \mathrm{hl}=\mathrm{e}$ n\&as sdt $=0$ \&as vis $=1 \&$ oi $=$ scholart\&sa $=X \& v$ ed=0ahUKEwjRjuycs6zQAhULqY8KHZQW CcQQgQMIGjAA

Yulianti Y. 2012. Analisis Partisipasi Masyarakat dalam Pelaksanaan Program Nasional Pemberdayaan Masyarakat (PNPM) Mandiri Perkotaan di Kota Solok. Artikel Ilmiah. Padang (ID): Universitas Andalas. 